\title{
Calcification in the planktonic foraminifera Globigerina bulloides linked to phosphate concentrations in surface waters of the North Atlantic Ocean
}

\author{
D. Aldridge, C. J. Beer, and D. A. Purdie \\ University of Southampton, National Oceanography Centre, Southampton, European Way, Southampton, SO14 3ZH, UK
}

Correspondence to: D. Aldridge (d.aldridge@ noc.soton.ac.uk)

Received: 30 June 2011 - Published in Biogeosciences Discuss.: 8 July 2011

Revised: 6 April 2012 - Accepted: 13 April 2012 - Published: 15 May 2012

\begin{abstract}
Marine calcifiers, such as planktonic foraminifera, form a major component of the global carbon cycle, acting as both a source and sink of $\mathrm{CO}_{2}$. Understanding factors that affect calcification in these organisms is therefore critical in predicting how the oceans will respond to increased $\mathrm{CO}_{2}$ concentrations in the atmosphere. Here, size-normalised weights (SNWs) of the planktonic foraminifera Globigerina bulloides, collected from the surface waters of the North Atlantic Ocean, are compared with in situ carbonate ion concentrations $\left(\left[\mathrm{CO}_{3}^{2-}\right]\right)$, sea-surface temperature, optimum growth conditions and nutrient concentrations. Changes in phosphate concentrations $\left(\left[\mathrm{PO}_{4}^{3-}\right]\right.$, range: $\left.0.04-0.39 \mu \mathrm{M}\right)$ explained the majority of G. bulloides SNW variation, with reduced test masses at higher concentrations. Two factors already known to influence calcification in foraminifers, $\left[\mathrm{CO}_{3}^{2-}\right]$ and temperature, were also positively correlated over the range of values examined $\left(148-181 \mu \mathrm{M} \mathrm{kg}^{-1}\right.$ and $10.3-$ $12.7^{\circ} \mathrm{C}$ respectively). No evidence was found for increased SNWs under apparent optimum growth conditions, indicated by G. bulloides abundances. However, "growth potentials" $(\mu)$, derived from modelled growth rates $\left(\mathrm{d}^{-1}\right)$, were positively correlated with SNWs, suggesting that this may be a better proxy for optimum growth conditions. These findings point to the potential importance of $\left[\mathrm{PO}_{4}^{3-}\right]$ in determining calcification intensities in foraminifera, a factor which has been overlooked by previous studies on these organisms. The confirmation of this via carefully controlled culture studies is recommended in the future.
\end{abstract}

\section{Introduction}

Marine calcifying organisms secrete shells of calcium carbonate $\left(\mathrm{CaCO}_{3}\right)$ and form a major component of the global carbon cycle, transferring approximately 3 billion tons of $\mathrm{CaCO}_{3}$ to the sea-floor annually (Milliman, 1993). While $\mathrm{CaCO}_{3}$ transferred to (and permanently buried at) the seafloor represents a long-term sink of carbon dioxide $\left(\mathrm{CO}_{2}\right)$, the production of $\mathrm{CaCO}_{3}$, releasing $\mathrm{CO}_{2}$ into the surrounding water, represents a source over shorter timescales (Purdie and Finch, 1994).

The oceans are estimated to have absorbed between 30 $40 \%$ of anthropogenically released carbon dioxide $\left(\mathrm{CO}_{2}\right.$; Sabine et al., 2004; Zeebe et al., 2008), thereby mitigating some of the effects of climate change. This, however, has come at the cost of reduced oceanic $p \mathrm{H}$ values (Caldeira and Wickett, 2003), a phenomenon termed "ocean acidification". The ongoing "acidification" of the oceans is proposed to have an adverse effect on marine calcifiers via shifts in seawater carbonate chemistry and associated reductions in carbonate ion concentrations $\left[\left(\mathrm{CO}_{3}^{2-}\right)\right]$ (e.g. Gattuso et al., 1998; Riebesell et al., 2000; Müller et al., 2010). However, a comparison of 18 calcifying organisms suggests that a range of responses to reduced $\left[\mathrm{CO}_{3}^{2-}\right]$ are likely (Reis et al., 2009). This is reinforced by studies on coccolithophores, which have found mixed responses in calcification under increased $p \mathrm{CO}_{2}$ conditions (Riebesell et al., 2000; Langer et al., 2006; Iglesias-Rodriguez et al., 2008).

Planktonic foraminifera are ubiquitous open ocean protozoans and comprise an estimated $23-56 \%$ of the total open ocean marine $\mathrm{CaCO}_{3}$ flux to the deep sea (Schiebel, 2002). Understanding the factors controlling calcification in 
these organisms is, therefore, critical in predicting how the oceanic carbon pump will respond to increased $p \mathrm{CO}_{2}$ in the atmosphere. Additionally, size-normalised weights (SNWs) of these organisms, which are essentially a measure of test (shell) thickness and therefore calcification intensity (the use of the term "calcification rate", commonly used for other marine calcifying organisms, is not appropriate for foraminifera as they build their chambers intermittently), are a potentially important proxy for enabling paleoatmospheric $p \mathrm{CO}_{2}$ variations beyond ice-core records to be evaluated (Spero et al., 1997). This is based on the assumption that SNWs of these organisms are strongly linked to $\left[\mathrm{CO}_{3}^{2-}\right]$, which in turn is used as a proxy for $p \mathrm{CO}_{2}$ in the atmosphere.

Planktonic foraminiferal SNWs are generally reduced under lower $\left[\mathrm{CO}_{3}^{2-}\right]$, although a large amount of inter and intraspecific diversity in response to $\left[\mathrm{CO}_{3}^{2-}\right]$ exists (see Table 1 for a summary). Temperature is known to affect the size of foraminifera (Bé et al., 1973; Hecht, 1976; Schmidt et al., 2004): in addition to being closely linked to $\mathrm{CO}_{2}$ solubility (and therefore $\left[\mathrm{CO}_{3}^{2-}\right]$ ), temperature also affects test size via changes in rates of enzymatic activity (Spero et al., 1991), feeding and digestion rates (Kooijmann, 2000), and stratification - which can lead to an increase in the number of pelagic niches (Schmidt et al., 2004). It is therefore likely that temperature also has an effect on SNWs of foraminifera.

There is a suggestion that SNWs may be greatest under optimum growth conditions (de Villiers, 2004), which are represented by the geographic location where each individual species is most abundant, either because favourable growth conditions result in higher calcification intensities, or a larger proportion of the population reaches maturity where calcite crust formation takes place (Hemleben et al., 1989). This hypothesis, however, is not supported in a recent comparison between SNWs and both the absolute and relative abundance of Globigerina bulloides and Globigerinoides rubber, using samples from the Arabian Sea (Beer et al., 2010a). This may be due to the fact that foraminifer abundance is not a good proxy for optimum growth conditions; or, alternatively, environmental controls in addition to $\left[\mathrm{CO}_{3}^{2-}\right]$ may influence foraminiferal calcification intensity and hence SNWs.

Furthermore, nutrient concentrations - both nitrate $\left(\mathrm{NO}_{3}^{-}\right)$ and phosphate $\left(\mathrm{PO}_{4}^{3-}\right)$ - are likely to be important in determining foraminiferal calcification intensities. In culture experiments, increased "water fertility" has been shown to result in larger test sizes via increases in prey availability (Bijma et al., 1992), but it is unknown whether concomitant increases in test thickness, and therefore SNWs, also occur. For example, it may be that high $\left[\mathrm{PO}_{4}^{3-}\right]$ actually reduces SNWs. Substantial evidence exists for the inhibition of calcification by $\mathrm{PO}_{4}^{3-}$, via the adsorption of calcium hydrogen phosphate $\left(\mathrm{CaHPO}_{4}\right)$ onto the calcite surface, blocking active crystal growth sites and slowing $\mathrm{CaCO}_{3}$ precipitation (Lin and Singer, 2006). Reduced calcification rates have been observed at elevated $\left[\mathrm{PO}_{4}^{3-}\right]$ in coral reefs (Kinsey and
Davies, 1979), calcifying green algae (Demes et al., 2009), and coccolithophores (Paasche and Brubank, 1994). However, the influence of $\left[\mathrm{PO}_{4}^{3-}\right]$ on foraminiferal calcification has yet to be investigated.

In order to investigate the environmental factor/s controlling calcification intensities of the planktic foraminifer Globigerina bulloides in the natural environment, SNWs of this species, from two size fractions $(150-200 \mu \mathrm{m}$ and 200 $250 \mu \mathrm{m})$ collected from surface waters at 10 locations in the North Atlantic Ocean, are compared to a number of environmental factors measured in situ: $\left[\mathrm{CO}_{3}^{2-}\right]$, optimum growth conditions (implied from chlorophyll $a$, nutrient concentrations, modelled growth rates $[\mu]$, and $G$. bulloides abundances), sea surface temperature (SST), and nutrient concentrations $\left(\mathrm{NO}_{3}^{-}\right.$and $\left.\mathrm{PO}_{4}^{3-}\right)$.

\section{Material and methods}

\subsection{Sample collection}

G. bulloides samples and in situ environmental data were collected from 10 locations in the North Atlantic (Fig. 1) on board the RRS Discovery D340a Extended Ellett Line Cruise between the 11th and 20th of June 2009. Specimens of $G$. bulloides were obtained as recommended by Hemleben et al. (1989) using a plankton net (with an opening of $0.196 \mathrm{~m}^{2}$ and a mesh size of $120 \mu \mathrm{m}$ ), fitted with a Hydrobios digital flowmeter, towed at the surface. This approach was used as planktonic foraminifera that are subjected to low temperatures (for example, when normally surface dwelling organisms sink into colder deep water) often undergo secondary thickening of their calcite wall, forming a "calcite crust" (Hemleben et al., 1989). However, there is still a potential bias in using plankton nets (compared to sediment traps or surface sediments) as the last chamber is not necessarily fully calcified upon collection, potentially biasing SNWs. Seawater samples were immediately preserved using formalin buffered with sodium borate $\left(30 \mathrm{~g} \mathrm{~L}^{-1}\right)$ to provide a final formalin concentration of $4 \%$ and a $p \mathrm{H}$ of 8.1.

\subsection{Isolation of $G$. bulloides specimens}

A $1 \mathrm{ml}$ sub-sample from each preserved plankton trawl was transferred to a $1 \mathrm{ml}$ glass Sedgewick-Rafter chamber, using an automatic pipette, following gentle inversion of the sample bottle to homogenize the contents. Individual specimens were removed under a dissecting microscope using a micropipette and transferred into de-ionised water (buffered with $7.8 \times 10^{-4} \mathrm{M}$ sodium tetraborate and $1.01 \times 10^{-3} \mathrm{M}$ sodium hydroxide). This buffer solution was chosen as it left minimal residue when foraminifera were dried (discussed below).

The above procedure was repeated until a minimum of 80 individuals had been isolated from each sample. Following this, hydrogen peroxide $\left(\mathrm{H}_{2} \mathrm{O}_{2}\right)$ was added to the buffered deionised water (final concentration of $3 \%$ ) in 
Table 1. Inter and intra-specific diversity in the response of different foraminifera species to $\left[\mathrm{CO}_{3}^{2-}\right]$. Studies that utilized data from: sediment cores (a), laboratory cultures (b), and plankton net samples (c) are shown.

\begin{tabular}{|c|c|c|c|}
\hline Species & {$\left[\mathrm{CO}_{3}^{2-}\right]$ positively related to $\mathrm{SNW}$} & $\begin{array}{l}{\left[\mathrm{CO}_{3}^{2-}\right] \text { negatively related }} \\
\text { to } \mathrm{SNW}\end{array}$ & No response to $\left[\mathrm{CO}_{3}^{2-}\right]$ \\
\hline Orbulina universa & $\begin{array}{l}\text { Spero et al. }(1997)^{\mathrm{b}} \\
\text { Bijma et al. }(1999)^{\mathrm{b}} \\
\text { Russell et al. }(2004)^{\mathrm{b}} \\
\text { Lombard et al. }(2010)^{\mathrm{b}}\end{array}$ & & \\
\hline Globorotalia truncatulinoides & $\begin{array}{l}\text { Barker and Elderfield }(2002)^{\mathrm{a}} \\
\text { Moy et al. }(2009)^{\mathrm{a}} \\
\text { de Villiers }(2004)^{\mathrm{a}} \\
\text { Gonzalez-Mora et al. }(2008)^{\mathrm{a}} \\
\text { Beer et al. }(2010 \mathrm{a})^{\mathrm{c}} \\
\text { This study } \\
\text { de Villiers }(2004)^{\mathrm{a}}\end{array}$ & & Bijma et al. (1999) ${ }^{b}$ \\
\hline Neogloboquadrina pachyderma & & & $\begin{array}{l}\text { de Villiers }(2004)^{\mathrm{a}} \\
\text { Gonzalez-Mora et al. } \\
(2008)^{\mathrm{a}}\end{array}$ \\
\hline Globigerinoides ruber & $\begin{array}{l}\text { de Moel et al. (2009) }{ }^{\mathrm{a}} \\
\text { Gonzalez-Mora et al. }(2008)^{\mathrm{a}}\end{array}$ & Beer et al. $(2010 a)^{c}$ & \\
\hline Globigerinoides sacculifer & Lombard et al. $(2010)^{b}$ & & \\
\hline
\end{tabular}

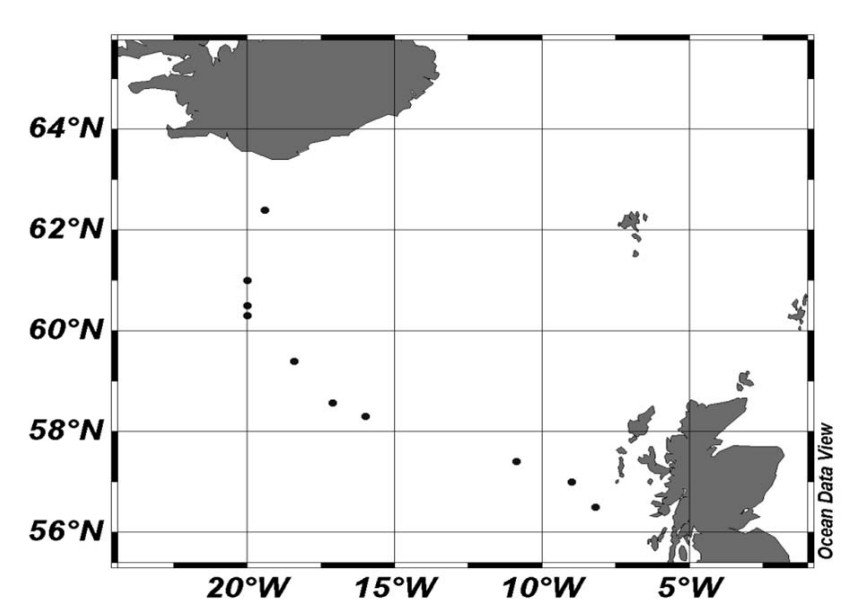

Fig. 1. Stations sampled during the D340a Extended Ellett Line Cruise to the North Atlantic in June 2009 (black dots).

order to dissolve any organic material adhering to the outside of the tests. After $45 \mathrm{~min}$, the foraminifera containing solution was decanted into a petri-dish. Foraminifera were transferred, using a micro-pipette, into another petri-dish and $5 \mathrm{ml}$ of buffered deionised water added to dilute any remaining $\mathrm{H}_{2} \mathrm{O}_{2}$, thereby adhering to the recommendations of Moy et al. (2009) of not exceeding $1 \mathrm{~h}$ in $\mathrm{H}_{2} \mathrm{O}_{2}$. Specimens were finally transferred onto pre-marked areas of petri-slides using a micro-pipette and left to evaporate in air. Once dried, specimens of G. bulloides were isolated from other species, according to the defining characteristics described by Bé (1977), and then separated into 2 size fractions (150-200 $\mu \mathrm{m}$ and $200-250 \mu \mathrm{m})$, using a calibrated microscope graticule.

\subsection{Calculation of $G$. bulloides abundance}

In order to quantify the number of $G$. bulloides, at each sample site, average abundances were determined in a $1 \mathrm{ml}$ aliquot, of the preserved net sample, transferred to a $1 \mathrm{ml}$ glass Sedgewick-Rafter chamber under a dissecting microscope. This was repeated on average 75 times (range: $27-$ 198). The mean numbers of $G$. bulloides per $\mathrm{ml}$ of sample were converted to numbers per $\mathrm{m}^{3}$ using the flowmeter readings.

At 3 of the 10 sites, the flowmeter recorded very little water flow over the 4-5 min sample period (less than $50 \mathrm{~m}^{3}$, see Table 2).This was unlikely to be a true reflection of the actual flow and is suspected to reflect a failure of the flowmeter. For these three net samples an estimate of the flow rate (AF) was calculated by dividing the total volume of water entering the net (TV) by the total time that the net was in the water (T), from the 7 samples where the flowmeter was deemed to have worked adequately (Eq. 1). For these 7 samples, net deployment time was positively, and significantly, correlated with the volume of water sampled (Linear regression: $R^{2}=0.58$, $\left.F_{1,6}=6.89, P=0.047\right)$.

$$
\begin{aligned}
& \mathrm{AF}=\frac{\mathrm{TV}\left(\mathrm{m}^{3}\right)}{T(s)} \\
& \mathrm{AF}=0.092 \mathrm{~m}^{3} \mathrm{~s}^{-1}
\end{aligned}
$$

This average flow rate (AF) was then multiplied by the number of seconds that the net was in the water (TW), for each of the 3 samples where the flowmeter failed, to provide an approximate volume of water passing through the net for these 
samples (AV) (Eq. 2).

$\mathrm{AV}=0.092 \mathrm{~m}^{3} \mathrm{~s}^{-1} \times \mathrm{TW}$

\subsection{SNW analysis}

SNWs are required to determine factors that affect test wall thickness and density, and therefore test weights of foraminifera. This works by removing the influence that test size has on weight: essential, as test-size has been shown to vary with ambient environmental conditions that occur during growth (Hecht, 1976; Schmidt et al., 2006). Two methods of determining SNWs are commonly used. The simplest method is to weigh specimens that have been picked from a narrow size fraction (typically $50 \mu \mathrm{m}$ ), with the data being termed the "sieve-based weight" (SBW; Broecker and Clark, 2001). The second method involves measuring the size (typically diameter or area) of each individual test picked from a narrow size fraction. Test weights are then normalised to the mean measured test size to obtain a "measurement-based weight" (MBW; e.g. Barker and Elderfield, 2002). Here the MBW method is used as SBWs are in part determined by test size (Beer et al., 2010b), implying that this is not an effective size-normalisation procedure. From this point on in the manuscript, wherever the abbreviation SNW is used in reference to our own results, it refers to weights that have been normalised (to test diameters) using the MBW method.

Following the measurement of test diameters, using micrograph images taken at a known magnification with an integrated microscope (Leica MZ8) and camera system (Nikon D5000 Digital SLR), G. bulloides specimens were weighed, in aluminium capsules $(5 \times 9 \mathrm{~mm})$, in groups of 10-25 individual tests, using a microbalance (Sartorius ME-5, precision $=1 \mu \mathrm{g}$ ). Weights were determined following transfer to an environmentally controlled weighing room for $2 \mathrm{~h}$, therefore allowing tests to equilibrate with the ambient atmospheric moisture content of the room.

During the measurement of test diameters, some foraminifera ( 57 out of 309 specimens) were found to be outside the desired size ranges (both size fractions; on average $\pm 17 \mu \mathrm{m})$. Specimens less than $25 \mu \mathrm{m}$ outside the desired size range (42/309) were included in the final analysis in order to maintain as large a sample size as possible. Although this increases the chance that individuals from different ontogenetic stages (therefore possessing a different number of chambers) were included, especially in the $150-200 \mu \mathrm{m}$ size fraction, the size-normalisation procedure should have reduced any effect that these small number of specimens (14\% of the total) had on the overall results.

Mean SBWs were calculated by dividing the average mass per sample (10-25 tests) by the number of G. bulloides in the sample. MBW for each sample was calculated by normalizing SBW to the mean diameter for the corresponding size fraction (Eq. 3).

$\mathrm{MBW}_{\text {diameter }}=\frac{\text { mean } \mathrm{SBW}_{\text {sample }} \times \text { mean diameter }_{\text {size fraction }}}{\text { mean diameter }}$

\section{$2.5\left[\mathrm{CO}_{3}^{2-}\right]$ measurements}

\subsubsection{Inorganic carbon sampling}

During the cruise, underway dissolved inorganic carbon (DIC)/alkalinity samples were taken from the sub-surface underway seawater supply (intake at $\sim 5 \mathrm{~m}$ depth) and stored in borosilicate glass bottles $(250 \mathrm{~mL})$. A saturated solution of mercuric chloride $\left(70 \mathrm{~g} \mathrm{~L}^{-1}\right)$ was added to the samples in a $0.02 \%$ volume ratio $(50 \mu \mathrm{L})$ in order to eradicate any biological activity; samples were then stored in the dark prior to analysis.

The VINDTA (Versatile Instrument for the Determination of Titration Alkalinity) was used to measure total alkalinity (TA) and DIC (Mintrop, 2005). TA was determined by titration of seawater with $0.1 \mathrm{M} \mathrm{HCL}$. Following this, the potential of a proton sensitive electrode was determined using a coulometer to measure the amount of $\mathrm{CO}_{2}$ released after the sample was mixed with phosphoric acid. Alkalinity was calculated using LabVIEW software, which uses the Gran (1952) technique to measure the alkalinity of seawater samples run with the VINDTA system. DIC was determined using a UIC Inc. Model $5012 \mathrm{CO}_{2}$ Coulometer in combination with the VINDTA system. Total DIC concentrations $\left(\mu \mathrm{M} \mathrm{kg}^{-1}\right)$ were calculated using VINDTA LabView software.

\subsubsection{Precision of the VINDTA instrument}

Precision of the VINDTA instrument was calculated using sub-standards prepared from the remnants of previous samples; the results were recorded and precision was calculated separately for TA and DIC (Eq. 4).

precision (TA or DIC)

$=$ standard deviation of substandards (TA or DIC)

Precision ranged between 0.7071 and $8.8526 \mu \mathrm{M} \mathrm{kg}^{-1}$ for DIC and between 0.4430 and $7.1842 \mu \mathrm{M} \mathrm{kg}^{-1}$ for alkalinity. Certified reference materials (CRMs) for oceanic $\mathrm{CO}_{2}$ measurements were used to calibrate and establish a correction factor for VINDTA measurements. Once the precision of the instrument had been checked, using the prepared substandards, the CRM samples were run using the VINDTA instrument; the results were subsequently used to calculate the necessary correction factor (Eq. 5).

correction factor $=\frac{\text { CRM value }}{\text { VINDTA value (TA or DIC) }}$ 
Table 2. Data obtained for each sample station during the D340a Extended Ellett Line cruise: *denotes sampled volumes where a correction factor was used (original values were: IB16 - 1.47, IB14 - no data; IB6 - 3.70); ${ }^{* *}$ denotes chlorophyll $a$ values that were obtained from the surface underway fluorometer rather than from discrete CTD Niskin bottle samples.

\begin{tabular}{|c|c|c|c|c|c|c|c|c|c|c|c|c|c|c|c|c|c|}
\hline \multirow[t]{2}{*}{ Station } & \multirow[t]{2}{*}{$\begin{array}{l}\text { Latitude } \\
\left({ }^{\circ} \mathrm{N}\right)\end{array}$} & \multirow[t]{2}{*}{$\begin{array}{l}\text { Longitude } \\
\left({ }^{\circ} \mathrm{W}\right)\end{array}$} & \multirow[t]{2}{*}{$\begin{array}{l}\text { Towing } \\
\text { duration } \\
\text { (secs) }\end{array}$} & \multirow[t]{2}{*}{$\begin{array}{l}\text { Volume } \\
\text { sampled } \\
\left(\mathrm{m}^{3}\right)\end{array}$} & \multirow{2}{*}{$\begin{array}{l}\text { In situ } \\
\text { foraminifer } \\
\text { abundance } \\
\text { (cells m }^{-3} \text { ) }\end{array}$} & \multicolumn{2}{|c|}{$\begin{array}{c}\text { Average } \\
\text { diameter } \\
(\mu \mathrm{m})\end{array}$} & \multicolumn{2}{|c|}{$\begin{array}{l}\text { Sieve-based } \\
\text { weight } \\
\text { (SBW) }\end{array}$} & \multicolumn{2}{|c|}{$\begin{array}{c}\text { Measurement-based } \\
\text { weight } \\
\text { (MBW) }\end{array}$} & \multirow[t]{2}{*}{$\begin{array}{l}\mathrm{PO}_{4}^{3-} \\
(\mu \mathrm{M})\end{array}$} & \multirow[t]{2}{*}{$\begin{array}{l}\text { Nitrate } \\
\left(+\mathrm{NO}_{2}^{-}\right) \\
(\mu \mathrm{M})\end{array}$} & \multirow[t]{2}{*}{$\begin{array}{l}\mathrm{CO}_{3}^{2-} \\
\left(\mu \mathrm{M} \mathrm{kg}^{-1}\right)\end{array}$} & \multirow[t]{2}{*}{$\begin{array}{l}\text { SST } \\
\left({ }^{\circ} \mathrm{C}\right)\end{array}$} & \multirow[t]{2}{*}{$\begin{array}{l}\text { Chlorophyll } a \\
\left(\mu \mathrm{gL}^{-1}\right)\end{array}$} & \multirow[t]{2}{*}{$\begin{array}{l}\text { Growth } \\
\text { potentia } \\
\left(\mu, d^{-1}\right.\end{array}$} \\
\hline & & & & & & $\begin{array}{l}150- \\
200, \mu \mathrm{m}\end{array}$ & $\begin{array}{l}200- \\
250, \mu m\end{array}$ & $\begin{array}{l}150- \\
200, \mu \mathrm{m}\end{array}$ & $\begin{array}{l}200- \\
250, \mu \mathrm{m}\end{array}$ & $\begin{array}{l}150- \\
200, \mu \mathrm{m}\end{array}$ & $\begin{array}{l}200- \\
250, \mu m\end{array}$ & & & & & & \\
\hline IB 19S & $62^{\circ} 40^{\prime}$ & $19^{\circ} 40^{\prime}$ & 269 & 22.46 & 24 & 171.25 & 215.28 & 1.00 & 1.75 & 1.09 & 1.94 & 0.31 & 12.35 & 151.98 & 10.4 & $0.69 * *$ & 0.101 \\
\hline IB16 & $60^{\circ} 50^{\prime}$ & $20^{\circ} 00^{\prime}$ & 329 & $30.60^{*}$ & 19 & 199.31 & 243.75 & 1.16 & 2.57 & 1.09 & 2.51 & 0.27 & 12.40 & 148.38 & 10.7 & 1.05 & 0.108 \\
\hline IB14 & $61^{\circ} 00^{\prime}$ & $20^{\circ} 00^{\prime}$ & 314 & $29.20^{*}$ & 24 & 171.18 & 235.61 & 0.96 & 1.80 & 1.04 & 1.82 & 0.39 & 13.63 & 148.96 & 10.9 & 0.70 & 0.106 \\
\hline IB 13 & $60^{\circ} 30^{\prime}$ & $20^{\circ} 00^{\prime}$ & 248 & 24.40 & 28 & 186.98 & 250.88 & 1.07 & 2.53 & 1.07 & 2.40 & 0.31 & 11.09 & 166.40 & 11.0 & 1.11 & 0.111 \\
\hline IB 10 & $59^{\circ} 40^{\prime}$ & $18^{\circ} 42^{\prime}$ & 302 & 34.34 & 13 & 201.39 & 248.68 & 1.73 & 2.42 & 1.60 & 2.32 & 0.18 & 4.40 & 163.09 & 11.4 & 1.22 & 0.116 \\
\hline IB6 & $58^{\circ} 57^{\prime}$ & $17^{\circ} 11^{\prime}$ & 259 & $24.09^{*}$ & 6 & 184.85 & 243.75 & 1.18 & 2.25 & 1.19 & 2.20 & 0.18 & 5.27 & 175.43 & 11.3 & $1.42 * *$ & 0.116 \\
\hline IB4 & $58^{\circ} 30^{\prime}$ & $16^{\circ} 00^{\prime}$ & 265 & 9.64 & 3 & 188.33 & 235.83 & 1.10 & 2.40 & 1.09 & 2.42 & 0.18 & 5.23 & 167.05 & 11.8 & 0.87 & 0.119 \\
\hline$K$ & $57^{\circ} 40^{\prime}$ & $10^{\circ} 87^{\prime}$ & 251 & 13.94 & 22 & 189.58 & 229.55 & 1.36 & 2.09 & 1.34 & 2.17 & 0.17 & 3.97 & 174.77 & 12.2 & $1.47 * *$ & 0.127 \\
\hline$R$ & $57^{\circ} 00^{\prime}$ & $09^{\circ} 00^{\prime}$ & 273 & 31.63 & 13 & 186.31 & 231.55 & 1.36 & 2.43 & 1.36 & 2.50 & 0.13 & 2.22 & 179.86 & 12.7 & 1.19 ** & 0.132 \\
\hline$T$ & $56^{\circ} 50^{\prime}$ & $08^{\circ} 20^{\prime}$ & 304 & 38.93 & 2 & 189.81 & 245.83 & 1.59 & 2.92 & 1.56 & 2.82 & 0.04 & 0.02 & 181.38 & 12.7 & $1.21 * *$ & 0.132 \\
\hline
\end{tabular}

The resulting correction factors for TA and DIC were applied to the sample measurements (Eq. 6).

final result $=$ VINDTA reading $\times$ correction factor

\subsubsection{Calculation of $\left[\mathrm{CO}_{3}^{2-}\right]$}

Given any two parameters of the carbonate system, one can determine the complete marine carbonate system. In this project the $\mathrm{CO}_{2}$ SYS.EXE programme, developed by Lewis and Wallace (1998), was used. The corrected DIC and TA values, derived from the VINDTA analyses, were inserted in the $\mathrm{CO}_{2}$ SYS.EXE programme together with input (temperature, pressure, $\left[\mathrm{PO}_{4}^{3-}\right]$ and silicate concentration) and output conditions (temperature and pressure) for each sample. As recommended by the software's instructions, input conditions were set as those of the laboratory conditions (i.e. a temperature of $25^{\circ} \mathrm{C}$ and pressure of 0 dbar). Output conditions were set as those when the sample was taken.

\subsection{Sea surface temperature (SST)}

Sea-surface temperature values were obtained from CTD data. Two CTD systems were used during the cruise: one housed in a standard stainless steel frame, and the other housed in a titanium frame. Both CTDs were equipped with dual temperature and conductivity sensors.

\subsection{Chlorophyll}

Samples were collected from CTD Niskin bottles and transferred into 1 litre pre-washed polycarbonate bottles prior to processing. Duplicate sub-samples of $0.5 \mathrm{~L}$, or $1 \mathrm{~L}$, were filtered under low vacuum through $47 \mathrm{~mm}$ GF/F glass fibre filters. Filters were stored in centrifuge tubes at $-20^{\circ} \mathrm{C}$ until later processing in the laboratory at the Scottish Association for Marine Science (SAMS). Chlorophyll was extracted overnight in the dark in $90 \%$ acetone at a constant temperature of $4{ }^{\circ} \mathrm{C}$. Samples were then sonicated and centrifuged prior to analysis of chlorophyll $a$ concentration using a Turner Designs Trilogy fluorometer.
At four of the stations (see Table 2), where discrete samples were not taken from Niskin bottles attached to the CTD, underway surface chlorophyll $a$ values were obtained from a fluorometer (WET Labs WETStar) attached to the ships underway seawater supply. Fluoresence data were logged as raw voltages and later converted into chlorophyll $a$ concentration from the manufacturer's suggested algorithm. Chlorophyll $a$ values were then calibrated, using discrete chlorophyll $a$ values obtained from CTD Niskin bottles.

\subsection{Modelled growth rates}

A model for determining the growth rates $\left(\mu, \mathrm{d}^{-1}\right)$ of several species of planktonic foraminifera (including G. bulloides) was recently devised by Lombard et al. (2011). The model estimates growth rate as a function of temperature and food concentration (estimated via organic carbon concentrations, which are estimated from chlorophyll $a$ data), and has been shown to be a good estimator of in situ growth rates - reproducing relative abundances of several species of foraminifera on a global scale. The model is used in the present study as a further proxy for "optimum growth conditions". Chlorophyll $a\left(\mu \mathrm{g} \mathrm{Chl} a \mathrm{~L}^{-1}\right)$ concentrations were converted to carbon biomass $\left(\mu \mathrm{g} \mathrm{CL}^{-1}\right)$ by using a C:Chl $a$ ratio of $20: 1$. This ratio depends on temperature, light, and nutrient availability (Taylor et al., 1997; Geider et al., 1997) and was estimated using outputs of the PISCES model (Aumont et al., 2003; Aumont and Bopp, 2006), which provides a realistic C:Chl $a$ ratio, taking into account the effect of seasons and hydrology.

\subsection{Dissolved inorganic nutrients}

Water samples were collected directly from the CTD Niskin water bottles into $250 \mathrm{ml}$ acid cleaned polythene bottles. Samples were stored at $4{ }^{\circ} \mathrm{C}$ prior to analysis within $24 \mathrm{~h}$ of collection. $\left[\mathrm{NO}_{3}^{-}\right]$(+nitrite) and $\left[\mathrm{PO}_{4}^{3-}\right]$ measurements were made in triplicate using a Lachat QuikChem 8500 flow injection autoanalyser, according to the manufacturers recommended procedures. Nutrient standards were prepared in deionised water and the samples run in a carrier stream of 
deionised water. Salt correction of the result was performed by running a small number of Low Nutrient Sea Water samples (OSIL, http://www.osil.co.uk, Batch LNS 17, Salinity 35) during each sample batch run and the mean concentration subtracted from sample results. A standard reference solution prepared from nutrient standard solutions, containing $1 \mu \mathrm{MPO}_{4}^{3-}$ and $10 \mu \mathrm{MNO}_{3}^{-}$was run at the start and end of each sample batch. As well as providing an independent check on analysis accuracy, it also provided a correction of calibration drift during the course of each sample batch analysis.

\subsection{Statistical analysis}

Parametric linear regressions were performed using SigmaStat statistical software in order to determine if the sizenormalisation procedure adequately isolated the influence of test wall thickness and density, from that of size, on test weight.

Canonical correlation analysis, a multivariate statistical model that enables the study of inter-relationships among (two or more) sets of multiple dependent and independent variables (Hair et al., 1998), was used in this study to study the inter-relationships between test-mass size fractions (150-200 $\mu \mathrm{m}$ and 200-250 $\mu \mathrm{m})$ and environmental factors $\left(\left[\mathrm{CO}_{3}^{2-}\right], \mathrm{SST},\left[\mathrm{PO}_{4}^{3-}\right],\left[\mathrm{NO}_{3}^{-}\right]\right.$, G. bulloides abundance, [chlorophyll $a$ ], and $\mu$ ). The analysis attempts to find an independent set of linear combinations of the original variables, termed canonical variates, in order to maximize the between set correlation of the original variables (Morrison, 1978).

\section{Results}

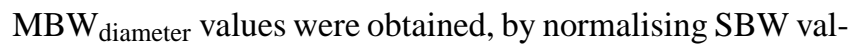
ues to mean diameters, and used in this study (as SNWs) in order to isolate the influence of test wall thickness and density, from that of size, on test weight. In order to determine if this size-normalisation method was effective, MBW and SBW were compared with mean test diameters (Fig. 2). There was a statistically significant relationship, in both size fractions, between SBW $(\mu \mathrm{g})$ and mean test diameters (Linear regression, 150-200 $\mu \mathrm{m}: R^{2}=0.47$, $F_{1,9}=6.98, P=0.030 ; 200-250 \mu \mathrm{m}: R^{2}=0.52, F_{1,9}=8.77$, $P=0.018$ ). No statistically significant relationships were observed when comparing MBWs with mean test diameters (Linear regression, $150-200 \mu \mathrm{m}: R^{2}=0.35, F_{1,9}=4.27$, $P=0.073 ; 200-250 \mu \mathrm{m}: R^{2}=0.34, F_{1,9}=4.04, P=0.079$ ).

A positive correlation between $\mathrm{SNWs}$ and $\left[\mathrm{CO}_{3}^{2-}\right]$ was observed for both size fractions (Fig. 3a: $150-200 \mu \mathrm{m}$, $R^{2}=0.35 ; 200-250 \mu \mathrm{m}, R^{2}=0.32$ ) over the sampled range of $\left[\mathrm{CO}_{3}^{2-}\right]\left(148.38-181.38 \mu \mathrm{M} \mathrm{kg}^{-1}\right)$. The sign, and gradient, of change is $+0.09 \mu \mathrm{g}$ per $10 \mu \mathrm{M} \mathrm{kg}^{-1}$ and $+0.13 \mu \mathrm{g}$ per $10 \mu \mathrm{M} \mathrm{kg}^{-1}$, for the $150-200 \mu \mathrm{m}$ and $200-250 \mu \mathrm{m}$ size fractions respectively.
In both the 150-200 and 200-250 $\mu \mathrm{m}$ size fractions, positive correlations between SNWs and SST (range: 10.4$12.7^{\circ} \mathrm{C}$ ) were observed (Fig. 3b: $150-200 \mu \mathrm{m}, R^{2}=0.44$; $200-250 \mu \mathrm{m}, R^{2}=0.36$ ). The gradients of change in SNW in response to SST were $+0.17 \mu \mathrm{g}(150-200 \mu \mathrm{m})$ and $+0.22 \mu \mathrm{g}$ (200-250 $\mu \mathrm{m})$ per $1{ }^{\circ} \mathrm{C}$.

SNWs were negatively, and weakly, correlated to in situ abundances of $G$. bulloides, which ranged between 2 and 28 cells $\mathrm{m}^{-3}$ (Fig. $3 \mathrm{c}$ : $150-200 \mu \mathrm{m}, R^{2}=0.24 ; 200-250 \mu \mathrm{m}$, $R^{2}=0.34$ ). Chlorophyll a concentration (range: 0.69$1.47 \mu \mathrm{g} \mathrm{L}^{-1}$ ), another potential proxy for optimum growth conditions, showed a weak positive correlation with SNWs in both size fractions (Fig. 3d: $150-200 \mu \mathrm{m}, R^{2}=0.32$; $\left.200-250 \mu \mathrm{m}, R^{2}=0.22\right)$. Growth potential $(\mu)$, however, was more strongly positively correlated with SNWs (Fig. 3e: $150-200 \mu \mathrm{m}, R^{2}=0.48 ; 200-250 \mu \mathrm{m}, R^{2}=0.41$ ).

SNWs were negatively correlated to $\mathrm{NO}_{3}^{-}(150-200 \mu \mathrm{m}$, $\left.R^{2}=0.64 ; 200-250 \mu \mathrm{m}, R^{2}=0.38\right)$ and $\mathrm{PO}_{4}^{3-}(150-200 \mu \mathrm{m}$, $R^{2}=0.62 ; 200-250 \mu \mathrm{m}, R^{2}=0.55$ ) concentrations (Fig. 3f, g). $\mathrm{NO}_{3}^{-}\left(+\mathrm{NO}_{2}^{-}\right)$concentrations ranged between 0.02 and $13.63 \mu \mathrm{M}$. The gradients of change in SNWs in response to $\mathrm{NO}_{3}^{-}$concentrations were $-0.35 \mu \mathrm{g}(150-200 \mu \mathrm{m})$ and $-0.37 \mu \mathrm{g}(200-250 \mu \mathrm{m})$ per $10 \mu \mathrm{M}$. $\left[\mathrm{PO}_{4}^{3-}\right]$ ranged between 0.04 and $0.39 \mu \mathrm{M}$. The gradients of change in test mass in response to $\left[\mathrm{PO}_{4}^{3-}\right]$ were $-1.60 \mu \mathrm{g}(150-200 \mu \mathrm{m})$ and $-2.11 \mu \mathrm{g}(200-250 \mu \mathrm{m})$ per $1 \mu \mathrm{M}$.

A strong positive correlation between concentrations of surface $\mathrm{NO}_{3}^{-}$and $\mathrm{PO}_{4}^{3-}$ was observed (Table 3: $R^{2}=0.94$ ). These nutrients, in turn, were negatively correlated to Chlorophyll $a$ concentrations $\left(R^{2}=0.43\right)$. The suggestion that SNWs decrease with increasing nutrient concentrations raised the question of how nutrient concentrations impacted upon G. bulloides abundance. Comparing G. bulloides abundance to $\mathrm{NO}_{3}^{-}$and $\mathrm{PO}_{4}^{3-}$ concentrations suggests that abundance increased with increasing concentrations of these two nutrients (Table 3: $\mathrm{PO}_{4}^{3-}, R^{2}=0.55 ; \mathrm{NO}_{3}^{-}, R^{2}=0.48$ ).

Statistical performance of the canonical correlation analysis is shown in Table 4. The two canonical variates ( $\mathrm{F} 1$ and F2) explained 95 and $86 \%$ of the variation in SNWs. Nutrient concentrations $\left(\mathrm{PO}_{4}^{3-}\right.$ and $\left.\mathrm{NO}_{3}^{-}\right)$correlated most strongly with the two canonical variates (F1 and F2, Table 3 and Fig. 4), followed by $\left[\mathrm{CO}_{3}^{2-}\right], \mu$, and SST; Chlorophyll $a$ and abundance were most weakly correlated. $\left[\mathrm{CO}_{3}^{2-}\right]$, SST and $\mu$, which correlated positively with SNWs in both size fractions, were all strongly associated with each other (Table 3 and Fig. 4). $\left[\mathrm{PO}_{4}^{3-}\right]$ and $\left[\mathrm{NO}_{3}^{-}\right]$, which correlated negatively with SNWs in both size fractions (and also $\left[\mathrm{CO}_{3}^{2-}\right]$, SST and $\mu$ ), were also strongly associated with each other. SNWs from both size fractions were not strongly associated, although a positive correlation did exist; in the smaller (150$200 \mu \mathrm{m})$ size fraction, SNWs were more closely correlated to $\left[\mathrm{NO}_{3}^{-}\right]$and chlorophyll $a$, and to a lesser extent SST and $\mu$, than in the larger (200-250 $\mu \mathrm{m})$ size fraction (Table 3). 

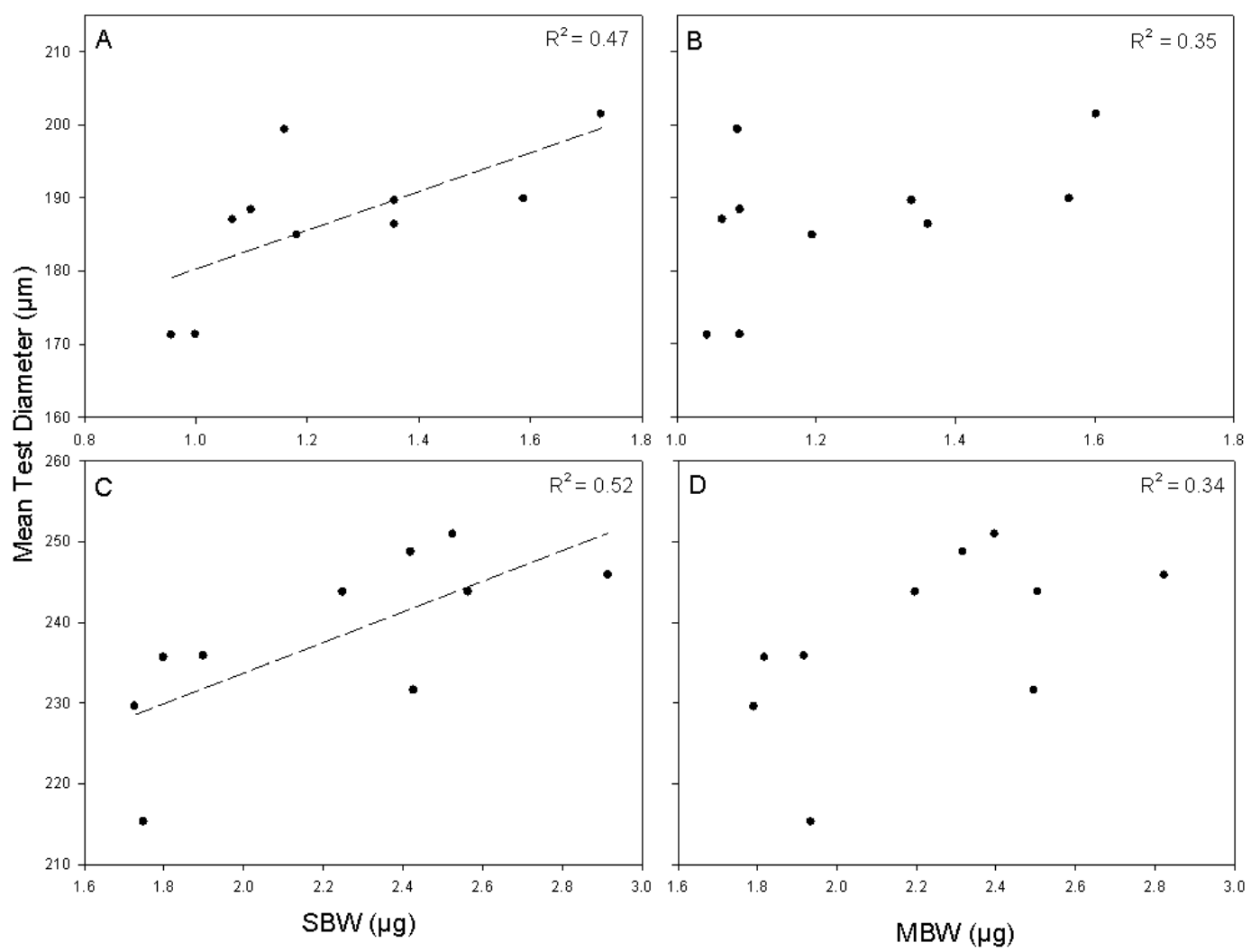

Fig. 2. The mean sieve-based weight (SBW; $\mu \mathrm{g}$ ) and measurement-based weight (MBW; $\mu \mathrm{g}$ ) versus the mean diameter ( $\mu \mathrm{m}$ ) for $G$. bulloides from 150-200 $\mu \mathrm{m}(\mathbf{A , B})$ and 200-250 $\mu \mathrm{m}$ (C, D) size-fractions. Dashed lines represent relationships that are statistically significant at the $95 \%$ confidence level.

Table 3. Correlation matrix of parameters measured (test masses and environmental variables).

\begin{tabular}{lrrrrrrrrr}
\hline Variables & $(150-200 \mu \mathrm{m})$ & $(200-250 \mu \mathrm{m})$ & $\mu$ & {$\left[\mathrm{CO}_{3}^{2-}\right]$} & $\mathrm{SST}$ & {$\left[\mathrm{PO}_{4}^{3-}\right]$} & {$\left[\mathrm{NO}_{3}^{-}\right]$} & Chl a & Abundance \\
\hline $\mathrm{SNW}(150-200, \mu \mathrm{m})$ & $\mathbf{1}$ & 0.493 & 0.695 & 0.589 & 0.660 & -0.786 & -0.801 & 0.569 & -0.465 \\
$\mathrm{SNW}(200-250, \mu \mathrm{m})$ & 0.493 & $\mathbf{1}$ & 0.642 & 0.563 & 0.603 & -0.741 & -0.619 & 0.423 & -0.576 \\
$\mu$ & 0.695 & 0.642 & $\mathbf{1}$ & 0.901 & 0.990 & -0.886 & -0.928 & 0.658 & -0.564 \\
$\mathrm{CO}_{3}^{2-}$ & 0.589 & 0.563 & 0.901 & $\mathbf{1}$ & 0.871 & -0.847 & -0.903 & 0.726 & -0.570 \\
$\mathrm{SST}$ & 0.660 & 0.603 & 0.990 & 0.871 & $\mathbf{1}$ & -0.860 & -0.909 & 0.558 & -0.577 \\
$\mathrm{PO}_{4}^{3-}$ & -0.786 & -0.741 & -0.886 & -0.847 & -0.860 & $\mathbf{1}$ & 0.967 & -0.655 & 0.780 \\
$\mathrm{NO}_{3}^{-}$ & -0.801 & -0.619 & -0.928 & -0.903 & -0.909 & 0.967 & $\mathbf{1}$ & -0.665 & 0.738 \\
Chlorophyll a & 0.569 & 0.423 & 0.658 & 0.726 & 0.558 & -0.655 & -0.665 & $\mathbf{1}$ & -0.293 \\
Abundance & -0.465 & -0.576 & -0.564 & -0.570 & -0.577 & 0.780 & 0.738 & -0.293 & $\mathbf{1}$ \\
\hline
\end{tabular}

The spatial distribution of test masses shows a broadly similar pattern for both size fractions (Fig. 5): generally, heavier test masses are found close to the west coast of Scotland (higher SST, $\mathrm{CO}_{3}^{2-}$ and $\mathrm{PO}_{4}^{3-}$ ) and lighter test masses are found close to Iceland (lower SST, $\mathrm{CO}_{3}^{2-}$ and $\mathrm{PO}_{4}^{3-}$ ). In the middle of the transect SNWs do not show an obvious progression, from north to south, towards heavier tests.

\section{Discussion}

\subsection{Effectiveness of the size-normalisation procedure}

While no statistically significant relationships were observed when comparing MBWs with mean test diameters for either size fraction, significant relationships were observed when comparing SBWs to test diameters. This suggests that the size-normalisation procedure employed as part of this study (i.e. using MBWs as opposed to SBWs) adequately isolates 

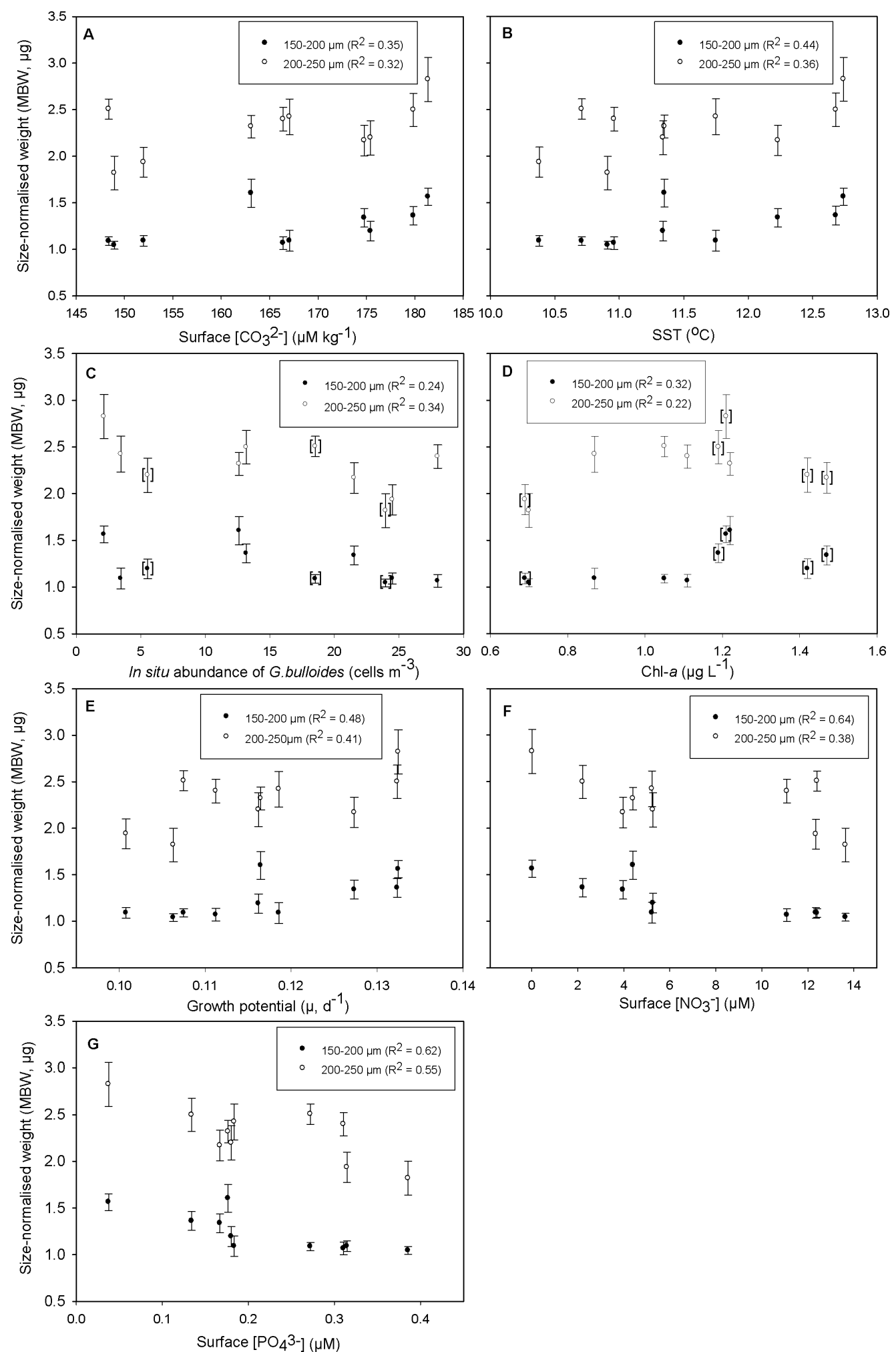

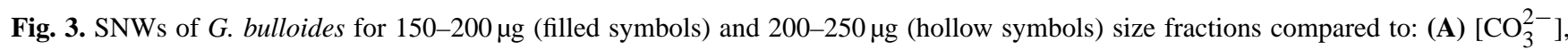
(B) sea surface temperature, (C) in situ abundance of G. bulloides (brackets around symbols denote values where a correction factor was applied), (D) chlorophyll $a$ (brackets around symbols denote where calibrated underway values have been used), (E) growth potential, (F) $\left[\mathrm{NO}_{3}^{-}\right]$and $(\mathbf{G})\left[\mathrm{PO}_{4}^{3-}\right]$. Error bars represent the reciprocal of the number of specimens weighed per aliquot multiplied by mean specimen weight. 
Table 4. Statistical performance of the canonical correlation analysis: canonical correlations (R), redundancy coefficients and eigenvalues are shown for the canonical variates (F1 and F2).

\begin{tabular}{lllll}
\hline & Canonical correlation $(\mathbf{R})$ & \multicolumn{2}{c}{ Redundancy coefficient } & Eigenvalue $\left(\right.$ Canonical $\left.R^{2}\right)$ \\
\hline & & Independent variables & Dependent variables & 0.95 \\
F1 & 0.98 & 0.50 & 0.26 & 0.86 \\
F2 & 0.93 & 0.41 & 0.29 & \\
\hline
\end{tabular}

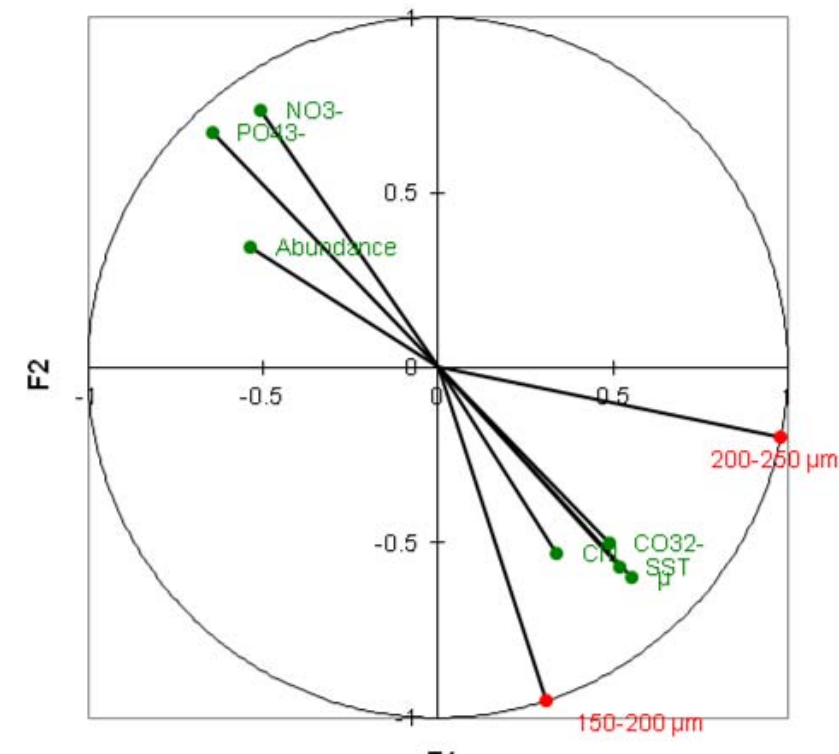

F1

Fig. 4. Canonical correlations between input variables (dependent and independent) and canonical variables (F1 and F2).

the influence of test wall thickness and density from that of size, on test weight. Therefore, we are confident that the SNWs used here are a good reflection of calcification intensity, and not simply test size.

\subsection{A Consideration of Potential Factors Controlling SNWs}

\subsection{1 $\left[\mathrm{CO}_{3}^{2-}\right]$}

The range of $\left[\mathrm{CO}_{3}^{2-}\right]\left(148-181 \mu \mathrm{M} \mathrm{kg}^{-1}\right)$ is smaller than in many previous studies, which have artificially imposed high $\left[\mathrm{CO}_{3}^{2-}\right]$ in culture (Spero et al., 1997; Bijma et al., 1999; Lombard et al., 2010) or used samples from sediment cores (Barker and Elderfield, 2002; Gonzalez-Mora et al., 2008; de Moel et al., 2009; Moy et al., 2009). Despite this, the sign and gradient of change observed here is comparable to those derived from $G$. bulloides specimens collected from surface waters in the Arabian Sea (Beer et al., 2010a), and Globigerinoides sacculifer and Orbulina universa specimens in culture (Bijma et al., 1999; Lombard et al., 2010). As the majority of studies to date have found SNWs to be positively related to
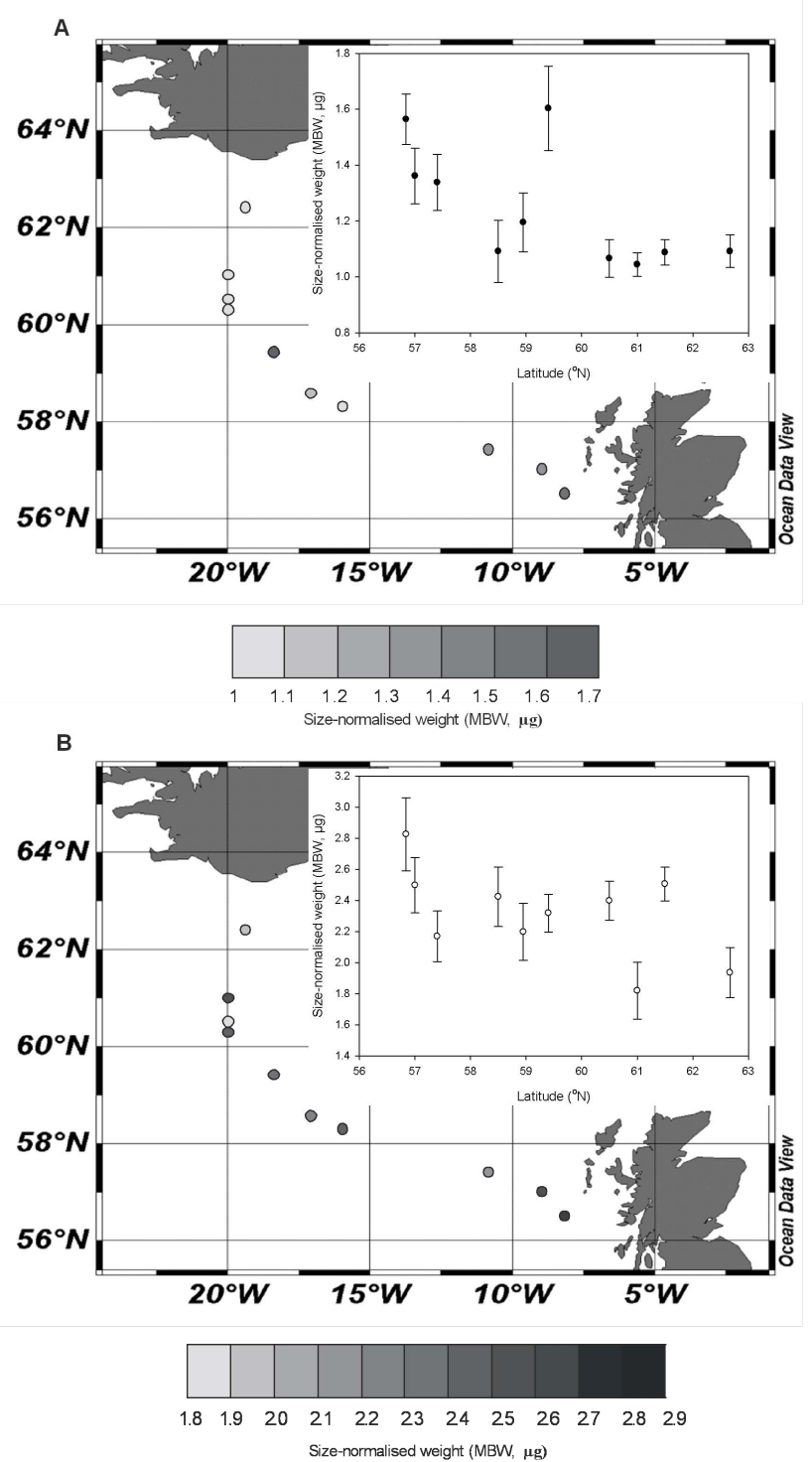

Fig. 5. The spatial distribution of $G$. bulloides SNWs in the North Atlantic, between Iceland and Scotland, for 150-200 $\mu \mathrm{m}$ (A) and 200-250 $\mu \mathrm{m}$ (B) size fractions. Inserted panels show SNW variations with latitude.

$\left[\mathrm{CO}_{3}^{2-}\right]$, not only in G. bulloides but also in other species of foraminifera (Table 1), it is likely that reductions in $\left[\mathrm{CO}_{3}^{2-}\right]$ 
in the future will adversely affect calcification in these organisms.

It would appear that species specific responses to reduced $\left[\mathrm{CO}_{3}^{2-}\right]$ exist in planktonic foraminifera (Table 1), as has been observed in studies on coccolithophores (Riebesell et al., 2000; Langer et al., 2006; Iglesias-Rodriguez et al., 2008), perhaps highlighting that $\left[\mathrm{CO}_{3}^{2-}\right]$ is a useful proxy but not necessarily a direct driver of calcification. Calcification tends not to occur at surfaces in direct contact with seawater, but in relatively isolated compartments within the cell (e.g. Erez, 2003; Bentov et al., 2009; de Nooijer et al., 2009). Additionally, ion transport channels tend to transport bicarbonate as opposed to carbonate ions (Carre et al., 2006): precipitating $\mathrm{CaCO}_{3}$ from $\mathrm{HCO}_{3}^{-}$and/or $\mathrm{CO}_{2}$ via a series of reactions (Portner, 2008). Therefore, the ability to modify carbonate chemistry within microenvironments, convert $\mathrm{HCO}_{3}^{-}$to $\mathrm{CO}_{3}^{2-}$, and/or utilize $\mathrm{HCO}_{3}^{-}$directly in calcification as is the case in coccolithophores (Paasche, 2002), may be the reason for the range of responses exhibited by different species of foraminifera to increased $p \mathrm{CO}_{2}$ in seawater.

$G$. bulloides is a non-symbiont bearing species. Foraminifera species that harbour algal symbionts may be better able to withstand reductions in $\left[\mathrm{CO}_{3}^{2-}\right]$ due to the production of ATP from photosynthesis, providing energy for concentration of inorganic carbon into vesicles, removal of ions that inhibit calcification (e.g. ter Kuile, 1991), and/or the conversion of $\mathrm{HCO}_{3}^{-}$to $\mathrm{CO}_{3}^{2-}$ via $p \mathrm{H}$ regulation at the site of calcification (Rink et al., 1998). Non-symbiont bearing species are likely to have a higher sensitivity to reduced $\left[\mathrm{CO}_{3}^{2-}\right]$. This is a factor that may explain the larger decrease of test weights between the last glacial maximum to present day conditions for G. bulloides (Barker and Elderfield, 2002; Moy et al., 2009) compared to the symbiotic G. ruber (de Moel et al., 2009), and the differences in response to $\left[\mathrm{CO}_{3}^{2-}\right]$ exhibited by these two species in the surface waters of the Arabian Sea (Beer et al., 2010a). However, a recent study by Fujita et al. (2011) demonstrates that it is important to be careful when extrapolating these responses to future ocean acidification scenarios. The effects of increased $p \mathrm{CO}_{2}$ on three species of symbiont-bearing reef foraminifers were examined, and although two of the species exhibited enhanced calcification at intermediate $p \mathrm{CO}_{2}$ values, further increases beyond $970 \mu \mathrm{atm}$ reduced calcification. Therefore, in the short term there may be winners and losers in response to ocean acidification amongst foraminifera; but in the long term, in the absence of any adaptive strategies, these organisms may find their geographical range restricted to lower latitudes where $\left[\mathrm{CO}_{3}^{2-}\right]$ will be highest (Feely et al., 2004).

\subsubsection{Temperature}

The positive trends observed between SST and SNWs were of the same order of magnitude as those observed when comparing $\left[\mathrm{CO}_{3}^{2-}\right]$ with SNWs. This is not surprising, as lower temperatures are responsible for reduced $\left[\mathrm{CO}_{3}^{2-}\right]$ at higher latitudes, due to increased solubility of atmospheric $\mathrm{CO}_{2}$. However, the fact that stronger relationships exist between SST and SNWs suggests that temperature may have an additional effect on SNWs.

In addition to having an effect on $\left[\mathrm{CO}_{3}^{2-}\right]$, temperature is also known to be an important control on the size of planktonic foraminifera (e.g. Bé et al., 1973; Hecht, 1976; Schmidt et al., 2004). The most likely mechanism by which temperature could increase SNWs is through increases in enzymatic activity, leading to faster growth due to enhanced calcification and cytoplasm synthesis (Spero et al., 1991). Temperature may also increase feeding and ingestion rates (Kooijman, 2000; Lombard et al., 2011), which could lead to higher growth rates; it is unknown, however, whether increases in test size also result in thicker, denser tests, and therefore increased SNWs. One final way in which temperature may affect SNWs may be indirectly via stratification, which increases the number of pelagic niches available, leading to ecological partitioning; this could potentially minimize inter-specific competition, allowing growth of foraminifers to larger sizes (Schmidt et al., 2004).

\subsubsection{Optimum growth conditions}

de Villiers (2004) suggested that SNWs are linked more closely to optimum growth conditions than $\left[\mathrm{CO}_{3}^{2-}\right]$. de Villiers used relative abundance as a proxy for optimum growth conditions, assuming that favourable environmental variables would result in greater abundances of foraminifera. Beer et al. (2010a) were unable to lend support to this hypothesis. Results from the current study also found no relationship between SNWs and G. bulloides abundances in both size fractions examined. In fact, SNWs were inversely related to $G$. bulloides abundances, the opposite trend to what would be expected under the optimum growth conditions hypothesis. Although three out of the ten abundance values were calculated using average flow rates, the abundance counts presented here are arguably more reliable than those used by de Villiers (2004), which relied on generalised geographic trends. Confidence can also be placed in these findings based on the high volume of sample that these abundance counts were based on (average of $75 \mathrm{ml}$; range: $27-198 \mathrm{ml}$ ), and the fact that abundances found here are in close agreement with expected abundances in the North Atlantic for this time of year (Schiebel and Hemleben, 2001).

Chlorophyll concentrations may also be considered as an alternative proxy for optimum growth conditions, as microalgae form a large component of the diet of G. bulloides (Schiebel et al., 1997). Nevertheless, only weak positive trends between SNWs and chlorophyll were observed, suggesting that the effect of optimum growth conditions on G. bulloides SNWs was minimal. However, a confounding factor when considering this proxy for optimum growth 
conditions is that, although nutrient concentrations $\left(\mathrm{PO}_{4}^{3-}\right.$ and $\mathrm{NO}_{3}^{-}$) and abundances of $G$. bulloides were positively correlated with each other, nutrient concentrations were inversely related to chlorophyll concentrations; this suggests that lower G. bulloides abundances were found at higher chlorophyll concentrations. As algae forms an important part of this species' diet (Hemleben et al., 1989), the opposite trend would be expected; the trend observed here probably reflects the fact that chlorophyll concentration is tightly coupled to grazing pressure (Sverdrup, 1953). Therefore, it is probably the rate of algal growth that is most important to G. bulloides abundance, and not absolute algal abundance implied from chlorophyll concentrations. If this is the case, then nutrient concentrations are probably a better proxy for optimum growth conditions in foraminifera. This has been suggested by studies where increased foraminifer abundances are associated with higher nutrient concentrations (Bé and Tolderlund, 1971; Hemleben et al., 1989; Schiebel et al., 2001). However, as will be discussed in more depth in the next section, SNWs were in fact lower at higher nutrient concentrations.

Finally, we used modelled G. bulloides growth rates ( $\mu$, $\mathrm{d}^{-1}$; Lombard et al., 2011), which took into account temperature and chlorophyll $a$ concentration, in order to better constrain the effects of "growth potential" on G. bulloides SNWs. In this model, water temperature is used to estimate prey capture and digestion in foraminifers, and chlorophyll is used as a proxy for prey concentration. Modelled growth rates were positively correlated with $G$. bulloides SNWs in both size fractions, suggesting that calcification rates may be higher when "growth potential" is higher. It may, therefore, be the case that abundance is not the best indicator of optimum growth conditions. However, this finding must be interpreted with caution, as this model is highly dependent on temperature to predict growth rates; as we have previously mentioned, temperature (in addition to its effects on $\left[\mathrm{CO}_{3}^{2-}\right]$ ) is likely to have an effect on foraminifer SNWs via its influence on enzymatic activity and size.

\subsubsection{Nutrient concentrations}

SNWs were inversely related to both $\mathrm{NO}_{3}^{-}$and $\mathrm{PO}_{4}^{3-}$ concentrations. As these nutrients were closely correlated to each other, it is difficult to infer whether this effect is due to the combination, or just one of these nutrients acting in isolation. There is, however, no evidence in the literature for reduced calcification in marine calcifying organisms under high $\mathrm{NO}_{3}^{-}$ concentrations.

Substantial evidence does exist for inhibition of calcification at high concentrations of $\mathrm{PO}_{4}^{3-} \cdot \mathrm{PO}_{4}^{3-}$ has long been recognized as an inhibitor of calcite formation, adsorbing onto the calcite surface, blocking active crystal growth sites and impeding calcite precipitation (e.g. Simkiss, 1964; Pytkowicz, 1973; Reddy, 1977; Mucci, 1986; House, 1987). Lin and Singer (2006) identified the $\mathrm{PO}_{4}^{3-}$ species responsible for this inhibition as calcium hydrogen phosphate $\left(\mathrm{CaHPO}_{4}\right)$, which alters the formation and subsequent growth of surface nuclei, resulting in reduced precipitation kinetics. Although there is no direct evidence for this phenomenon occurring in planktonic foraminifera, studies have been carried out on other marine calcifiers. For example, coccolithophores grown in $\mathrm{PO}_{4}^{3-}$ replete medium have been demonstrated to have lower calcification rates than cells grown under $\mathrm{PO}_{4}^{3-}$ limited conditions (Paasche and Brubank, 1994), while $\mathrm{PO}_{4}^{3-}$ concentrations of $20 \mu \mathrm{M}$ have been shown to decrease biomineralisation in the calcifying green alga Halimeda incrassata by 15 $\%$ (Demes et al., 2009). Similarly, a $>50 \%$ reduction in coral calcification has been attributed to elevated $\mathrm{PO}_{4}^{3-}$ concentrations $(2 \mu \mathrm{M})$, maintained via discontinuous fertilisation over an 8 month period (Kinsey and Davies, 1979). Although the $\mathrm{PO}_{4}^{3-}$ concentrations in these experiments are at least 5 times greater than the highest concentrations found in the present study $(0.39 \mu \mathrm{M})$, there is indirect evidence for inhibition of calcification at concentrations much closer to these values: one of the highest $\mathrm{PO}_{4}^{3-}$ concentrations reported for waters in direct proximity to a coral reef $(0.6 \mu \mathrm{M})$, is associated with one of the lowest overall calcification rates (Smith and Kinsey, 1976). This suggests that $\left[\mathrm{PO}_{4}^{3-}\right]$ may be the main factor influencing SNWs of foraminifera in the present study.

Nutrient concentrations $\left(\mathrm{PO}_{4}^{3-}\right.$ and $\left.\mathrm{NO}_{3}^{-}\right)$and $G$. bulloides abundances were positively correlated with each other, a finding that is consistent with previous observations (e.g. Bé and Tolderlund, 1971; Hemleben et al., 1989; Schiebel et al., 2001). Taken together with reduced SNWs at high $\left[\mathrm{PO}_{4}^{3-}\right]$, this suggests that high nutrient concentrations could lead to a larger number of organisms with thinner tests. This may be explained in two ways: higher nutrient concentrations may favour increased growth and reproduction of G. bulloides, resulting from the increased abundance of their microalgal prey, but at the price of thinner tests resulting from $\mathrm{PO}_{4}^{3-}$ inhibition of calcification; alternatively, increased growth and reproductive output are energetically costly to individual G. bulloides, which subsequently invest less energy into calcification, resulting in thinner tests. These two explanations may not necessarily be mutually exclusive and, once again, separating out the effects of $\mathrm{NO}_{3}^{-}$and $\mathrm{PO}_{4}^{3-}$ is beyond the scope of the particular observational approach adopted here.

\subsubsection{Spatial distribution of test masses}

Test masses were heaviest closest to the west coast of Scotland, and lightest towards Iceland. These values had a large impact on the trends observed, and interestingly tests did not, on the whole, become progressively heavier in between these locations. This suggests that control of test mass may not primarily have been caused by a factor which steadily changed over the sampled transect: factors such as SST, $\left[\mathrm{CO}_{3}^{2-}\right]$ and $\mu$. This would explain why test masses correlated best with $\left[\mathrm{PO}_{4}^{3-}\right]$, as this was highest near to Iceland, lowest off the west coast of Scotland, and relatively stable in between. 
It is possible that different genotypes of $G$. bulloides exhibit different calcification responses to the same environmental factors, as is the case in the coccolithophore Emiliania huxleyi (Langer et al., 2009). It is considered that there are two genotypes of $G$. bulloides in the high latitude North Atlantic: Type IIa and Type IIb. Generally, Type IIa is found to the west of the Reykjanes Ridge (south-west of Iceland), and Type IIb is found to the East of the Reykjanes Ridge (Stewart et al., 2001); however, although Type IIb appears to be confined to the east, Type IIa is not necessarily confined to the west. The most likely explanation for this partial segregation is the water-mass transition that occurs, from the warm Irminger current (which flows around Iceland), to the cold East Greenland Current (which passes north to south down the east coast of Greenland). If this is the case, then it may be that Type IIa is able to tolerate greater temperatures to the east of the Reykjanes Ridge, whereas Type IIb may be intolerant of colder waters. What is relevant to the present study is the speculation by Stewart et al. (2001) that the relative distribution of these two genotypes may follow the northward progression of the spring bloom. If this occurs, then this would be another possible explanation why SNWs were a lot lighter towards Iceland than off the coast of Scotland: the differences observed may be due to the domination of the population by a single genotype at high and low latitudes, with a mix of the two genotypes occurring at intermediate latitudes. Information on calcification responses, in these two genotypes, to a range of environmental variables, combined with distributions for the specific area studied here, for this time of year, would be required to assess whether this a plausible explanation for the trends observed.

\subsubsection{Differing SNW response between size fractions}

Although positively correlated with each other, the association between the two size fractions was not as strong as one might expect, suggesting that calcification in different life-stages of $G$. bulloides is affected to a different extent by the various environmental variables examined here - a pattern that was observed in the data: SNWs in the smaller size fraction were more strongly (positively) correlated to $\left[\mathrm{NO}_{3}^{-}\right]$ and chlorophyll $a$, and to a lesser extent SST and $\mu$, which is perhaps not surprising as these factors are all known to positively impact the growth of G. bulloides (Bijma et al., 1992; Lombard et al., 2011), and would intuitively be more important in organisms that were further from maturity. We, therefore, tentatively propose that life-stage is likely to play a role in the response of foraminifer SNWs to various environmental factors in the ocean, with SNWs of "less mature" organisms being more dependent on factors known to impact growth rates.

\section{Summary and conclusions}

Our findings point to the potential importance of $\left[\mathrm{PO}_{4}^{3-}\right]$ in determining foraminiferal test masses in the ocean via inhibition of calcification, a factor which has been overlooked by previous studies on these organisms. Although changes in $\left[\mathrm{PO}_{4}^{3-}\right]$ explain the majority of the variation in SNWs in the current study, it is important to stress that the relationships observed here do not necessarily imply causality. Culture studies are perhaps best suited for assessing those environmental factors that are simply correlated with SNWs of foraminifera and those which exert control. This is especially important considering that the SNW of an existing test has a certain "memory"; therefore, although our measurements will have been skewed towards the time of sampling (because last chambers contribute disproportionately to test mass), SNWs are likely to represent a broader range of spatial and temporal influences than it is possible to capture using the point measurement approach adopted here.

Temperature, $\left[\mathrm{CO}_{3}^{2-}\right]$ and growth potential also appear to have an impact on SNWs, despite the fact that the ranges of temperature and $\left[\mathrm{CO}_{3}^{2-}\right]$ were narrow in comparison to $\left[\mathrm{PO}_{4}^{3-}\right]$; however, these three factors were closely linked to each other, making it difficult to separate out their effects on SNWs. The positive trends observed using a modelled measure of "growth potential" to represent optimum growth conditions, compared to using G. bulloides abundances, chlorophyll $a$ concentration, or nutrient concentration as a proxy, suggests that this may be the best method for assessing the effects of optimum growth conditions on foraminifer calcification in the future.

Finally, SNWs of smaller organisms were more strongly influenced by factors that are known to influence growth, than larger organisms, suggesting that factors controlling calcification in foraminifera are likely to change depending on life-stage.

Acknowledgements. First of all we would like to thank Jelle Bijma, Fabien Lombard and two anonymous reviewers for their helpful comments and suggestions that have greatly strengthened this manuscript. We are grateful to all of the scientific and technical crew onboard the D340a Extended Ellett Line cruise for their assistance in collecting samples, but especially Victoire Rerolle, for collecting and analysing the DIC data; Jamie Macrae, for analyzing the chlorophyll data; Tim Brand, for performing the nutrient analysis; and John Beaton for his technical advice and assistance in deploying the plankton net. We would also like to thank Toby Tyrrell for his helpful suggestions and comments. The Extended Ellet line cruise was funded by the Natural Environment Research Council's Oceans 2025 programme.

Edited by: G. Herndl 


\section{References}

Aumont, O. and Bopp, L.: Globalizing results from ocean in situ iron fertilization studies, Global Biogeochem. Cy., 20, GB2017, doi:10.1029/2005GB002591, 2006.

Aumont, O., Maier-Reimer, E., Blain, S., and Monfray, P.: An ecosystem model of the global ocean including $\mathrm{Fe}$, Si, P colimitations, Global Biogeochem. Cy., 17, 1060, doi:1010.1029/2001GB001745, 2003.

Barker, S. and Elderfield, H.: Foraminiferal calcification response to glacial-interglacial changes in atmospheric $\mathrm{CO}_{2}$, Science, 297 , 833-836, 2002.

Bé, A. W. H.: An ecological, zoogeographic and taxonomic review of recent planktonic foraminifera, in: Oceanic Micropaleontology, Vol. 1, edited by: Ramsay, A. T. S., Academic Press, London, 1-100, 1977.

Bé, A. W. H. and Tolderlund, D. S.: Distribution and ecology of living planktonic foraminifera in surface waters of the Atlantic and Indian Oceans, in: Micropaleontology of Oceans, edited by: Funnell, B. M. and Riedel, W. R., Cambridge University Press, London, 105-149, 1971.

Bé, A. W. H., Harrison, S. M., and Lott, L.: Orbulina universa d'Orbigny in the Indian Ocean, Micropalaeontology, 19, 150192, 1973.

Beer, C. J., Schiebel, R., and Wilson, P. A.: Testing planktic foraminiferal shell weight as a surface water $\left[\mathrm{CO}_{3}^{2-}\right]$ proxy using plankton net samples, Geology, 38, 103-106, 2010a.

Beer, C. J., Schiebel, R., and Wilson, P. A.: Technical Note: Determining the size-normalised weight of planktic foraminifera, Biogeosciences Discuss., 7, 905-920, doi:10.5194/bgd-7-905-2010, 2010b.

Bentov, S., Brownlee, C., and Erez, J.: The role of seawater endocytosis in the biomineralization process in calcareous foraminifera, PNAS, 106, 21500-21504, 2009.

Bijma, J., Hemleben, C., Oberhänsli, H., and Spindler, M.: The effects of increased water fertility on tropical spinose planktonic foraminifers in laboratory cultures, J. Foramin. Res., 22, 242256, 1992.

Bijma, J., Spero, H. J., and Lea, D. W.: Reassessing foraminiferal stable isotope geochemistery: Impact of the oceanic carbonate system (experimental results), in: Uses of Proxies in Paleoceanography: Examples from the South Atlantic, edited by: Fischer, G. and Wefer, G., Springer Verlag, Berlin-Heidelberg, 489512, 1999.

Broecker, W. S. and Clark, E.: Glacial-to-Holocene redistribution of carbonate ion in the deep sea, Science, 294, 2152-2155, 2001.

Caldeira, K. and Wickett, M. E.: Anthropogenic carbon and ocean pH, Nature, 425, 365, 2003.

Carre, M., Bentaleb, I., Bruguier, O., Ordinola, E., Barrett, N. T., and Fontugne, M.: Calcification rate influence on trace element concentrations in aragonitic bivalve shells: evidences and mechanisms, Geochim. Cosmochim. Ac., 70, 4906-4920, 2006.

Demes, K. W., Bell, S. S., and Dawes, C. J.: The effects of phosphate on the biomineralization of the green alga, Halimeda incrassata (Ellis) Lam, J. Exp. Mar. Biol. Ecol., 374, 123-127, 2009.

de Moel, H., Ganssen, G. M., Peeters, F. J. C., Jung, S. J. A., Kroon, D., Brummer, G. J. A., and Zeebe, R. E.: Planktic foraminiferal shell thinning in the Arabian Sea due to anthropogenic ocean acidification?, Biogeosciences, 6, 1917-1925, doi:10.5194/bg-61917-2009, 2009.

de Nooijer, L. J., Toyofuku, T., and Kitazato, H.: Foraminifera promote calcification by elevating their intracellular pH, PNAS, 106, 15374-15378, 2009.

de Villiers, S.: Optimum growth conditions as opposed to calcite saturation as a control on the calcification rate and shell-weight of marine foraminifera, Mar. Biol., 144, 45-49, 2004.

Erez, J.: The source of ions for biomineralization in foraminifera and their implications for paleoceanographic proxies, Rev. Mineral Geochem., 54, 115-149, 2003.

Feely, R. A., Sabine, C. L., Lee, K., Berelson, W., Kleypas, J., Fabry, V. J., and Millero, F. J.: Impact of anthropogenic $\mathrm{CO}_{2}$ on the $\mathrm{CaCO}_{3}$ system in the oceans, Science, 305, 362-66, 2004.

Fujita, K., Hikami, M., Suzuki, A., Kuroyanagi, A., Sakai, K., Kawahata, H., and Nojiri, Y.: Effects of ocean acidification on calcification of symbiont-bearing reef foraminifers, Biogeosciences, 8, 2089-2098, doi:10.5194/bg-8-2089-2011, 2011.

Gattuso, J. P., Frankignoulle, M., Bourge, I., Romaine, S., and Buddemeier, R. W.: Effect of calcium carbonate saturation of seawater on coral calcification, Global Planet. Change, 18, 37-46, 1998.

Geider, R. J., MacIntyre, H. L., and Kana, T. M.: Dynamic model of phytoplankton growth and acclimation: Responses of the balanced growth rate and the chlorophyll $a$ :carbon ratio to light, nutrient-limitation and temperature, Mar. Ecol. Prog. Ser., 148, 187-200, 1997.

Gonzalez-Mora, B., Sierro, F. J., and Flores, J. A.: Controls of shell calcification in planktonic foraminifers, Quaternary Sci. Rev., 27, 956-961, 2008.

Gran, G.: Determination of the equivalence point in potentiometric titrations part II, The Analyst, 77, 661-671, 1952.

Hair, J. F., Anderson, R. E., Tatham, R. L., and Black, W. C.: Multivariate data analysis, 6th Edn., Prentice-Hall, New Jersey, 928 pp., 2005.

Hecht, A. D.: An ecological model for test size variation in recent planktonic foraminifera: Applications to the fossil record, J. Foramin. Res., 6, 295-311, 1976.

Hemleben, C., Spindler, M., and Anderson, O. R.: Modern Planktonic Foraminifera, Springer-Verlag, New York, 1989.

House, W. A.: Inhibition of calcite crystal growth by inorganic phosphate, J. Colloid Interf. Sci., 119, 505-511, 1987.

Iglesias-Rodriguez, M. D., Halloran, P. R., Rickaby, R. E. M., Hall, I. R., Colmenero-Hidalgo, E., Gittins, J. R., Green, D. R. H., Tyrrell, T., Gibbs, S. J., von Dassow, P., Rehm, E., Armbrust, E. V., and Boessenkool, K. P.: Phytoplankton calcification in a high-CO2 world, Science, 320, 336-340, 2008.

Kinsey, D. W. and Davies, P. J.: Effects of elevated nitrogen and phosphorous on coral reef growth, Limnol. Oceanog., 24, 935940, 1979.

Kooijman, S. A. L. M.: Dynamic energy and mass budgets in biological systems, 2nd edition., Cambridge University Press, Cambridge, 424 pp., 2000.

Langer, G., Geisen, M., Baumann, K.-H., Klas, J., Riebesell, U., Thoms, S., and Young, J. R.: Species specific responses of calcifying algae to changing seawater carbonate chemistry, Geochem. Geophy. Geosy., 7, Q09006, doi:10.10.1029/2005GC001227, 2006. 
Langer, G., Nehrke, G., Probert, I., Ly, J., and Ziveri, P.: Strain-specific responses of Emiliania huxleyi to changing seawater carbonate chemistry, Biogeosciences, 6, 2637-2646, doi:10.5194/bg-6-2637-2009, 2009.

Lewis, E. and Wallace, D. W. R.: Program developed for $\mathrm{CO}_{2}$ system calculations, Oak Ridge, Oak Ridge National Laboratory, ORNL/CDIAC-105, 1998.

Lin, Y.-P. and Singer, P. C.: Inhibition of calcite precipitation by orthophosphate: speciation and thermodynamic considerations, Geochim. Cosmochim. Ac., 70, 2530-2539, 2006.

Lombard, F., Labeyrie, L., Michel, E., Bopp, L., Cortijo, E., Retailleau, S., Howa, H., and Jorissen, F.: Modelling planktic foraminifer growth and distribution using an ecophysiological multi-species approach, Biogeosciences, 8, 853-873, doi:10.5194/bg-8-853-2011, 2011.

Lombard, F., da Rocha, R. E., Bijma, J., and Gattuso, J.-P.: Effect of carbonate ion concentration and irradiance on calcification in planktonic foraminifera, Biogeosciences, 7, 247-255, doi:10.5194/bg-7-247-2010, 2010.

Milliman, J. D.: Production and accumulation of calcium carbonate in the ocean: budget of a nonsteady state, Global Biogeochem. Cy., 7, 927-957, 1993.

Mintrop, L.: The Versatile Instrument for the Determination of Titration Alkalinity; manual for versions $3 \mathrm{~s}$ and $3 \mathrm{c}$, Marianda, 2, 2005.

Morrison, D. F.: Multivariate Statistical Methods, 2nd Edn., McGraw-Hill, Tokyo, 415 pp., 1978.

Moy, A. D., Howard, W. R., Bray, S. G., and Trull, T. W.: Reduced calcification in modern Southern Ocean planktonic foraminifera, Nat. Geosci., 2, 276-280, 2009.

Mucci, A.: Growth kinetics and composition of magnesium calcite overgrowths precipitated from seawater-quantitative influence of ortho-phosphate ions, Geochim. Cosmochim. Ac., 50, 2255-2265, 1986.

Müller, M. N., Schulz, K. G., and Riebesell, U.: Effects of long-term high $\mathrm{CO}_{2}$ exposure on two species of coccolithophores, Biogeosciences, 7, 1109-1116, doi:10.5194/bg-7-1109-2010, 2010.

Paasche, E.: Roles of nitrogen and phosphorus in coccolith formation in Emiliania huxleyi (Prymnesiophyceae), Eur. J. Phycol., 33, 33-42, 1998.

Paasche, E.: A review of the coccolithophorid Emiliania huxleyi (Prymnesiophyceae), with particular reference to growth, coccolith formation, and calcification-photosynthesis interactions, Phycologia, 40, 503-529, 2002.

Paasche, E. and Brubank, S.: Enhanced calcification in the coccolithophorid Emiliania huxleyi (Haptophyceae) under phosphorus limitation, Phycologia, 22, 324-330, 1994.

Pörtner, H. O.: Ecosystem effects of ocean acidification in times of ocean warming: a physiologist's view, Mar. Ecol. Prog. Ser., 373, 203-217, 2008

Purdie, D. A. and Finch, M. S.: Impact of a coccolithophorid bloom on dissolved carbon dioxide in sea water enclosures in a Norwegian fjord, Sarsia, 79, 379-387, 1994.

Pytkowicz, R. M.: Calcium carbonate retention in supersaturated seawater, Am. J. Sci., 273, 515-522, 1973.

Reddy, M. M.: Crystallization of calcium carbonate in the presence of trace concentrations of phosphorous-containing anions: I. Inhibition by phosphate and glycerophosphate ions at $\mathrm{pH} 8.8$ and $25^{\circ} \mathrm{C}$, J. Cryst. Growth, 41, 287-295, 1977.
Riebesell, U., Zondervan, I., Rost, B., Tortell, P. D., Zeebe, R. E., and Morel, F. M. M.: Reduced calcification of marine plankton in response to increased atmospheric $\mathrm{CO}_{2}$, Nature, 407, 364-367, 2000.

Ries, J., Cohen, A., and McCorkle, D.: Marine calcifiers exhibit mixed responses to $\mathrm{CO}_{2}$-induced ocean acidification, Geology, 37, 1131-1134, 2009.

Rink, S., Kühl, M., Bijma, J., and Spero, H. J.: Microsensor studies of photosynthesis and respiration in the symbiotic foraminifer Orbulina universa, Mar. Biol., 131, 583-595, 1998.

Russell, A. D., Hosnisch, B., Spero, H.J., and Lea, D.W.: Effects of seawater carbonate ion concentration and temperature on shell $\mathrm{U}$, $\mathrm{Mg}$, and $\mathrm{Sr}$ in cultured planktonic foraminifera, Geochim. Cosmochim. Acta, 68, 4347- 4361, 2004.

Sabine, C. L., Feely, R. A., Gruber, N., Key, R. M., Lee, K., Bullister, J. L., Wanninkhof, R., Wong, C. S., Wallace, D. W. R., Tilbrook, B., Millero, F. J., Peng, T. H., Kozyr, A., Ono, T., and Rios, A. F.: The oceanic sink for anthropogenic CO2, Science, 305, 367-371, 2004.

Schiebel, R.: Planktic foraminiferal sedimentation and the marine calcite budget, Global Biogeochem. Cy., 16, 1065, 2002.

Schiebel, R. and Hemleben, C.: Planktonic Foraminifera, in: Encyclopedia of Ocean Sciences, edited by: Steele, J., Thorpe, S., and Turekian, K., Academic Press Ltd., London, UK, 308-2314, 2001.

Schiebel, R., Bijma, J., and Hemleben, C.: Population dynamics of the planktic foraminifer Globigerina bulloides from the eastern North Atlantic, Deep-Sea Res. Pt. I, 44, 1701-1713, 1997.

Schiebel, R., Waniek, J., Bork, M., and Hemleben, C.: Planktic foraminiferal production stimulated by chlorophyll redistribution and entrainment of nutrients, Deep-Sea Res. Pt. I, 48, 721-740, 2001.

Schmidt, D. N., Renaud, S., Bollmann, J., Schiebel, R., and Thierstein, H. R.: Size distribution of Holocene planktic foraminifer assemblages: biogeography, ecology and adaptation, Mar. Micropaleontol., 5, 319-338, 2004.

Simkiss, K.: Phosphates as crystal poisons of calcification, Biology Review, 39, 487-505, 1964.

Smith, S. V. and Kinsey, D. W.: Calcium carbonate production, coral reef growth, and sea level change, Science, 194, 937-939, 1976.

Spero, H. J., Lerche, I., and Williams, D. F.: Opening the carbon isotope 'vital effect' box. 2. Quantitative model for interpreting foraminiferal carbon isotope data, Paleoceanography, 6, 639$655,1991$.

Spero, H. J., Bijma, J., Lea, D. W., and Bemis, B. E.: Effect of seawater carbonate concentration on foraminiferal carbon and oxygen isotopes, Nature, 390, 497-500, 1997.

Stewart, I. A., Darling, K. F., Kroon, D., Wade, C. M., and Troelstra, S. R.: Genotypic variability in subarctic Atlantic planktic foraminifera, Mar. Micropal., 43, 143-153, 2001.

Sverdrup, H. U.: On conditions for the vernal blooming of phytoplankton, Journal du Conseil International pour l'Exploration de la Mer, 18, 287-295, 1953.

Taylor, A. H., Geider, R. J., and Gilbert, F. J. H.: Seasonal and latitudinal dependencies of phytoplankton carbon-to-chlorophyll $a$ ratios: Results of a modelling study, Mar. Ecol. Prog. Ser., 152, 51-66, 1997. 
ter Kuile, B.: Mechanisms for calcification and carbon cycling in algal symbiont-bearing foraminifera, in: Biology of Foraminifera, edited by: Lee, J. J. and Anderson, O. R., Academic Press, 7389, 1991.
Zeebe, R. E., Zachos, J. C., Caldeira, K., and Tyrrell, T.: Carbon emissions and acidification, Science, 321, 51-52, 2008. 